\title{
Effect of profitability and dividend policy on corporate governance and firm value: Evidence from the Indonesian manufacturing Sectors
}

\author{
*Muhammad Tamrin ${ }^{1)}$, H. Rahman Mus ${ }^{2)}$, Sudirman ${ }^{3)}$, Aryati Arfah ${ }^{4)}$ \\ ${ }^{1)}$ Doctoral Student in the Faculty of Economics, University of Muslim Indonesia \\ ${ }^{2,3,4)}$ Faculty of Economics, University of Muslim Indonesia \\ Corresponding Author: Muhammad Tamrin
}

\begin{abstract}
This study aims to analyze the effect of Profitability and Corporate Governance Structure on dividend policy and its impact on the firm value. The population in this research is manufacturing companies listed in Indonesia Stock Exchange as many as 146 companies. The research sample as many as 58 companies, the period of 2013 to 2015. Sampling technique used is purposive sampling. The data analysis technique used is WrapPLS. The results showed that profitability have a negative and significant effect on dividend policy. Profitability has a negative and significant effect on firm value. Profitability is a negative and insignificant effect on firm value as a mediated dividend policy. The structure of corporate governance is positive and significant effect on dividend policy. Corporate governance structure has a positive and significant effect on firm value. Corporate governance structure has a positive and insignificant effect on firm value as a mediated dividend policy. Dividend policy is a positive and insignificant effect on firm value.
\end{abstract}

Keywords: Profitability, corporate governance, dividend policy and firm value

\section{Introduction}

In their classic survey of corporate governance, Shleifer \& Vishny (1997) outline their focus in the following way: "Our perspective on corporate governance is a straightfor-ward agency perspective, sometimes referred to as separation of ownership and control. We want to know how investors get the managers to give them back their money." In the US and UK and many other Anglo-Saxon countries there is wide agreement that this is what corporate governance is about. The law is clear that shareholders are the owners of the firm and managers have a fiduciary (i.e., very strong) duty to act in their interests, and most of the academic literature on governance has taken this perspective (Becht, Bolton, \& Roell, 2003). However, moving beyond the cases of the US and UK, firms' objectives vary by country and often deviate significantly from the paradigm of shareholder value maximization. As Denis \& McConnell (2003) point out in their survey of international corporate governance: "in many European countries shareholder wealth maximization has not been the only - or even necessarily the primary - goal of the board of directors." To provide one example, in Germany the legal system is quite explicit that firms have a duty to pursue the interests of parties beyond just shareholders. The Germans have the system of co-determination, in which employees and shareholders in large corporations have an equal number of seats on the supervisory board of the company, so that the interests of both must be taken into account (Rieckers \& Spindler, 2004; Schmidt, 2004).

The synergistic effect of the investment policy, financing and dividend the company is the main goal of the policy makers in enhancing the value of the company, so that these policies are interrelated with each other. This condition is unique, because on the one hand the dividend policy is very important to meet the expectations of shareholders to dividends and reduce the agency problem and on the other hand how this dividend policy can be done without having to inhibit the growth of the company (Qureshi, 2006). The issue of corporate governance (CG) has attracted international attention and debate because of a series of corporate failures and the collapse of respected companies such as Enron, WorldCom, and Arthur Andersen. It raised a lot of concerns about the reliability of financial reporting and the efficiency of the existing monitoring mechanism within the company. In commenting on this scandal, various parties stated that the board of directors and audit committee does not have a good control (Al-Matari et al., 2012). Past studies have found evidence that managerial ownership has no effect on the value of the company because the management does not have control of the company and more controlled management of majority owner (Adnantara, 2013).

Institutional ownership is the percentage of shares held by institutional investors such as insurance companies, investment companies, and banks (Moradi et al., 2012). Institutional investors can play a role in 
monitoring the agent (manager) of the company. In addition, institutional investors have better access to information for their investment activity, which means a better knowledge about the company's performance (Ellili \& Farouk, 2011: 67). Predictions that the large institutional investors who have a positive influence on the value of the company, such a condition born out of the assumption that investors have an incentive to monitor management and efficiently (Navissi \& Naiker, 2006: 102).

Many companies are not essentially perform full control of the public companies so that managers can make decisions that more flexibility in the management of enterprise management (Saputra, 2012). Independent commissioner can also be used to resolve conflicts agency for independent directors to communicate the purpose of the shareholders to managers. Commissioners are at the core of corporate governance duty to ensure the company's strategy, to supervise the managers, and require effective accountability within the company (Purwaningtyas \& Pangestuti, 2011: 237). The addition of independent board members in the company can not affect the value of the company for possible additional members just to meet the rules (Carningsih, 2010: 312)

Dividend policy is a very important decision in the company. This policy will involve two parties have different interests, namely the first party, the shareholders and the management company itself. Management of the company has two treatment alternatives to net income or earnings after tax after tax. The two alternatives are distributed to shareholders in the form of dividends and through investment back into the company as retained earnings. In the company in general, the majority of earnings after tax distributed in the form of dividends and partly through investments, meaning that the management should make a dividend policy concerning the use of profits to the entitlement of the shareholders to determine the amount of earnings after tax were divided as dividends and the amount of earnings after tax withheld (Ratih, 2011: 210). Dividends are a part of the profits from the company and given by companies to shareholders in exchange for agreeing to instill his treasure in the company (Rudianto, 2009: 308), in addition to improving the welfare of the owners of the company, the dividend payment affect the value of the company, therefore, has special position for shareholders (Mehrani et al., 2011:198).

The amount of dividends distributed by a company can influence stock prices because investors prefer returns come from dividends compared with capital gains or in other words, investors prefer profits in dividends than expected gains from capital appreciation. Bird in the hand theory asserts that shareholders prefer high dividends because it has a high certainty than capital gains (Hermuningsih \& Wardani, 2009: 415). The higher dividend payout ratio will be more beneficial to shareholders because of the greater level of return on shares held (Darsono, 2009: 58). In the capital market activity, investors have expectations of its investments, namely in the form of capital gains and dividends (Marlina \& Danica, 2009). For the shareholders who do not like risk would prefer to receive dividends rather than capital gains. Dividends that exist today have a higher value than the capital gain that will be received in the future. This is in accordance with the bird in the hand theory. Thus shareholders who fear the risk would be better liked receive dividends rather than capital gains (Gordon, 1962; Linter, 1962).

The fact that firm value can be increased by a concern for stakeholders raises the possibility that shareholders may want to put in place governance structures that commit them to adopt a concern for other stakeholders even when not required to do so. We show that, when a firm anticipates a sufficiently large reaction from its rival, it can improve its shareholders' welfare by voluntarily choosing to take into account other stakeholders. We also show that, even in circumstances where firms may not voluntarily adopt a stakeholder orientation, such governance structures may nevertheless arise endogenously if consumers are more willing to buy from firms that care about stakeholders other than shareholders.' Interestingly, this leads to a situation of selfenforcing societies where consumers induce firms to adopt stakeholder concerns and consequently increase the value to shareholders.

\subsection{Profitability}

\section{Review of Literature}

Profitability is the company's ability to generate profits at the rate of sales, assets and certain capital. Thus, long-term investors will very concern with profitability analysis, for example for the shareholders, the shareholders will see profit actually be received in the form of dividends. In this study, the profitability measured by return on assets (Ismiyanti \& Hanafi, 2003: 8). Companies with levels of profitability high dividends in low numbers, otherwise if the company received a lower profitability, the company will increase the payment of dividends, it is intended to maintain the reputation of the company in good standing in the eyes of investors (Jensen, Solberg \& Zorn, 1992; cited in Nuringsih 2005: 1 5).

According to Gitman (2003: 145), profitability is the relationship between revenues and costs are generated using company assets both current and fixed in operating activities. Profitability demonstrates the ability of capital invested in total assets to generate profits. The higher level of profitability of the possibility of dividend distribution is also greater profitability is the company's ability to earn income or profit impact on 
dividend policy. If the company has a high level of profitability, the company will gain high profits and ultimately profit available for distribution as dividends to shareholders will be greater. The greater the profits from the company, the payment of dividends to shareholders or allocated to retained earnings will be greater (Sartono, 2001: 123). Profitability affect the dividend policy for the dividend is a portion of the net income of the company. Therefore, the dividend will be distributed if the company's profit. A decent profit and will be distributed to the shareholders is profit after the company meet its fixed obligations i.e. interest and taxes. That the greater Companies the benefit would pay the larger share of revenue as a dividend (Sudarsi, 2002: 79).

\subsection{Structure of Corporate Governance (SCG)}

There is a long tradition in finance going back to at least Jensen and Meckling (1976) of viewing corporate governance as being about how to resolve agency issues. In this view, different stakeholders such as employees and bondholders need to be provided with the correct incentives and this is why they may need to be included in the governance process. The foundation of this approach is that while shareholders own the firm and their objective is to maximize its value, they are not necessarily directly involved in running the firm. In contrast, in our analysis there is no agency problem, and our starting point is that many countries have in place legal requirements that stakeholders be included in the governance process. There are several variations in the implementation of the Corporate Governance mechanism (CG). CG is the factors that have a significant impact on increasing the market value of shares of the company (Black, Jang \& Kim, 2003). One of the goals of the company is to maximize shareholder value through dividends and increases in stock prices. The higher level of the stock price can be increasing the level of shareholders wealth. With the high firm value, it is expected shareholding welfare (Penman, 2004: 43; in Tarjo, 2008).

The emergence of the need for separation between ownership and managers can be effect of the agency problem. The problem is caused by the difference in interest between the principal (owner or shareholder) and the agent (manager). Agency problems cannot be separated from the tendency of managers to seek their own advantage (opportunistic behavior) at the expense of the interests of others. This occurs because although the manager obtain compensation from his job, but in reality very small changes in wealth manager than wealth changes owners / shareholders (Jensen \& Murphy, 1990: 75). Efforts to reduce opportunistic managerial behavior and increase the value of the company it is necessary to control through mechanisms of good corporate governance (GCG). There is a strong and positive relationship between the level of corporate governance and corporate value. In addition to their research results prove that the value of the relevant attribute corporate governance in enhancing the value of the company is corporate social behavior (Amman, Oesch \& Schmid, 2009).

One important element of corporate governance is transparency or openness. Openness is an act to explain everything that is done by the management company to the public. Transparency is not easy to do if the management has no interest and private information that supports their interests. Such a condition can occur if the management company who have a stake there as the owner (managerial ownership). The greater the percentage of managerial ownership, the possibility to do a little more openness, so that companies are more at risk (Iskandar \& Chamlou, 2000: 23).

\subsection{Firm value}

Research shows that firm value has a positive effect on the capital structure. The size of a large company are more likely to get a loan for external funding with the trend that companies are growing rapidly have to rely on external borrowing to meet the needs of the operational funds of the company (Wimelda \& Marlina, 2013: 25; Rahman \& Trianni, 2013: 15). A company with high growth, the trend of using debt is greater than the firms with lower growth rates. While the level of positive sales growth, the company will tend to take on debt in order to increase production capacity and sales (Priambodo et al. 2014: 40). Companies that grow rapidly will rely more on external funds. This makes the sales growth rate has a positive effect on the capital structure. Increasing the level of sales growth will be followed by increasing debt. The debt is expected to be paid out of the profits obtained from the increase of sales growth.

The size of the company is the average total net sales for the year to several years. In this case the sales greater than the variable costs and fixed costs, the obtained amount of income before taxes. Conversely, if the sale is smaller than the variable costs and fixed costs, the company will suffer a loss (Brigham \& Houston, 2001: 150). Company size is one of the variables to be considered in determining a company's value. The size of the company is a reflection of total assets, total capital and the total of sales owned by a company. Companies themselves are categorized into two types, namely small companies and large-scale enterprises. Empirical facts provide evidence that the size of the company and significant positive effect on firm value (Obradovich, \& Gill, 2013: 121). The study's findings differ from the results of other studies, that the size of the company and significant negative effect on firm value (Naceur \& Goaied, 2002: 90). The size of the company has a negative correlation with the firm value. Investors in capital include also need to look at the size of the company 
(Desemliyanti, 2003: 20). Firm size is a positive and significant effect on the firm value (Gill \& Obradovich, 2012; Prasetyorini, 2013; Maryam, 2014; Rachmawati \& Triatmoko, 2007). The firm size has a negative and significant value (Mas'ud, 2006).

A large-scale company whose shares are so widespread, every expansion of the share capital has only a small effect on the possibility of loss or displacement of the dominant control of the company concerned. In contrast, small companies, in which shares are distributed only in a small neighborhood, increasing the number of shares have a considerable effect on the possibility of loss of control of the dominant party of the company concerned. Thus, a large bolder company issuing new shares to meet the need to finance growth in sales compared to small-scale enterprises (Riyanto, 2010: 53). From his research obtained by empirical evidence that small firms are at risk and higher returns than large companies (Miswanto. H, 1999).

\subsection{Dividend Payout Ratio (DPR)}

Successful companies earn income. This income can be invested in operating assets, used to acquire securities, used to retire debt, or distributed to shareholders. The income distributed to shareholders is the dividend. Issues that arise if a company decides to distribute its income to shareholders include the proportion to which such income would be distributed to shareholders; whether the distribution should be as cash dividends, or the cash be passed on to shareholders by buying back some shares; and how stable the distribution should be. Much controversy surrounds dividends policy. Many reasons exist why companies should pay or not to pay dividends. Yet figuring out why companies pay dividends and investors pay attention to dividendthat is the "dividend puzzle" is still problematic. The dividend puzzle and noted that some important questions remained unanswered.

Percentage of profit paid out to shareholders in the form of a cash dividend payout ratio (DPR) (Brigham \& Gapenski, 1996; Rosdini, 2009). The magnitude of the Parliament determined the company every year (Brigham \& Gapenski, 1996). Dividend policy is basically the determination of the portion of profits will be given to shareholders. Dividend payment policy is important regarding whether cash flows will be paid to the investor or to be detained for reinvested by the company. In this study, measured using the dividend policy Dividend Payout Ratio (DPR) (Brigham \& Houston, 2001: 65). A company's value is not determined by the size of the House of Representatives, but is determined by the net profit before tax (EBIT) and grade corporate risk (Modigliani \& Miller, 1958). Empirical facts provide evidence that the variable Net Organizational Capital and the size of the company affect the dividend payout ratio while the variable ownership in, the concentration of ownership, free cash flow, and the growth rate does not affect the dividend payout ratio. The concentration of ownership is most shares owned by certain parties, for example, are owned by institutions, families and others (Atika, 2002).

Dividend policy is a decision to make an investment return on the profits derived from the company's operating results or to distribute to shareholders Investor). According Sadalia (2010) the payment of cash dividends to shareholders decided by the board of commissioners. Commissioners generally hold a meeting to determine the amount of the dividend to be paid, in determining the amount of dividends to be distributed need to evaluate the financial position of the last period and the financial position that will come. Dividend policy is very important for the financial manager as it involves two parties that share apprentices and companies that may have different interests. Dividend is defined as payments to shareholders by companies on profits earned in the form of cash or another instance of stock dividends and an extra dividends. Dividend policy is a policy, the stability of dividends and dividend growth. When dividends are paid all interests neglected reserves, otherwise if all retained earnings without Policy. Thus, dividend policy is a source of conflict between management and shareholders (Ahmad, 2007). Companies grow and develop, then in time to gain or profit. This profit consists of retained earnings and profits are shared. In the next phase of retained earnings is one of the most important sources of funds for financing the company's growth. The larger the enterprise financing from the retained earnings plus depreciation of fixed assets, the more robust the financial position of the company. From all the profits from the company partially distributed to shareholders in the form of dividends. Regarding the determination of the amount of dividends to be declared is what the dividend policy of the company leadership (Dermawan Sjahrial, 2002: 305),

\section{Method And Research Approach}

This study used two approaches, namely descriptive research and explanatory research. This study focused on empirical testing to wake up the model developed based on the proposed basic theoretical models (the proposed grand theoretical model). Model studies is comprised of: (1) model of research on the effects of profitability on dividend policy and the enterprise value (2) model of research on the influence of corporate governance structure on dividend policy and corporate value, and (3) model of research on the effects of dividend policy on firm value mediated by the dividend policy. The population was all firms in the manufacturing industry category listed in Indonesia Stock Exchange. The number of companies listed in 
Indonesia Stock Exchange until December 2015 as many as 148 manufacturing companies. The sampling technique used in this research is purposive sampling using several criteria in order to obtain the total sample of 58 industrial companies listed on the Indonesian Stock Exchange (BEI) in a row from 2013 to 2015. Data were obtained by utilizing the IDX website (Indonesian Stock Exchange) and ICDM (Indonesian Capital Market Directory).

\subsection{Profitability}

\section{Results}

In order to analyze the research data, the first financial data collected is processed into financial ratios profitability. The results of the calculation of financial ratios can be seen in the following table:

Table 1. Profitability

\begin{tabular}{|l|c|c|c|c|}
\hline \multirow{2}{*}{ Indicators } & \multicolumn{3}{|c|}{ Average } & \multirow{2}{*}{ Total } \\
\cline { 2 - 5 } & 2013 & 2014 & 2015 & \\
\hline Profit Margin & 8,458 & 8,314 & 8,626 & 8,466 \\
\hline ROA & 13,188 & 13,729 & 12,947 & 13,288 \\
\hline ROE & 11,360 & 9,088 & 7,650 & 9,366 \\
\hline
\end{tabular}

Based on the description of the indicators it can be concluded that the profitability fluctuates due to political turmoil in the country that have an impact on the sales decline in a long time, especially in manufacturing companies export import

\subsection{Corporate governance structure (CGS)}

In analyzing the study data, the first financial data collected was processed into the financial ratios of corporate governance structure. The results of the calculation of financial ratios can be seen in the following table:

Table 2. Corporate Governance Structure

\begin{tabular}{|l|r|r|r|r|}
\hline \multirow{2}{*}{ Indicators } & \multicolumn{3}{|c|}{ Average } & \multirow{2}{*}{ Total } \\
\cline { 2 - 5 } & \multicolumn{2}{|c|}{2013} & \multicolumn{1}{c|}{2014} & \multicolumn{1}{c|}{2015} \\
\hline Total Assets FS & 1217,914 & 1310,017 & 1536,983 & 1354,971 \\
\hline Total capital FS & 642,224 & 791,353 & 943,310 & 792,296 \\
\hline Total Sales FS & 1561,931 & 1689,945 & 1774,538 & 1675,471 \\
\hline Institutional Ownership & 43,571 & 43,208 & 44,189 & 43,656 \\
\hline Independent Commissioner & 4,569 & 4,621 & 4,621 & 4,603 \\
\hline
\end{tabular}

The manufacturing sectors run transformation of savings in all areas to offset the decline in demand by launching efficiency programs and implementation of information technology strictly so that total assets, total capital, and total sales increasing every year

\subsection{Dividend Policy}

In order to analyze the research data, the first financial data collected is processed into a ratio financial or dividend policy ratio. The results of the calculation of financial ratios can be seen in the following table:

Table 3. Dividend Policy

\begin{tabular}{|l|r|r|r|r|}
\hline \multirow{2}{*}{ Indicators } & \multicolumn{3}{|c|}{ Average } & \multirow{2}{*}{ Total } \\
\cline { 2 - 5 } & 2013 & 2014 & 14,507 & 16,728 \\
\hline EPS & 16,078 & 19,600 & 35,238 & 35,527 \\
\hline DPR & 34,524 & 36,819 & 5,761 & 6,351 \\
\hline Dividend Yield & 7,342 & 5,950 & & \\
\hline
\end{tabular}

Corporate governance structure associated with determining the amount of the dividend payout ratio, i.e. the percentage of net profit after tax which is distributed as dividends to shareholders. Dividend decision is part of the learning enterprise decisions, particularly with regard to the company's internal learning. This is because the size of the dividend will affect the size of the retained earnings. Retained earnings are one source of internal funds. 
1.8. Firm value

Results calculation of financial ratios for the company's value can be shown as follows:

Table 4. Firm value

\begin{tabular}{|c|c|c|c|c|}
\hline \multirow{2}{*}{ Indicators } & \multicolumn{3}{|c|}{ Average } & \multirow{2}{*}{ Total } \\
\hline & 2013 & 2014 & 2015 & \\
\hline PER & 16,957 & 19,243 & 13,618 & 16,606 \\
\hline PBV & 1,958 & 2,182 & 3,029 & 2,390 \\
\hline
\end{tabular}

Firm value in this study consisted of, the price earnings ratio (PER) price-book value (PBV). The results showed that during the period 2013 to 2015 the firm value has fluctuated from year to year with the average over the three years amounted to $16.606 \%$, the highest PER value occurred in 2014, namely sebesar19,243\%, while the lowest occurred in 2015 amounted to $13.618 \%$, Similarly, the PBV during the period 2013 to 2015 has increased from year to year with an average of three years of 2,390\%, the highest value PBV occurred in 2015 amounted to $3.029 \%$, while the lowest occurred in 2013 amounted to $1.958 \%$

\section{Hypothesis Testing}

The verification of hypothesis study used a cut-off value and p-value $<0.05$ (Sholihin, 2013). Thus, if the $\mathrm{p}$-value on a track that tested $<0.05$, the research hypothesis is proven. The test results are presented path coefficients in the following table:

Table 5. Hypothesis Results

\begin{tabular}{|c|c|c|c|c|c|c|}
\hline \multirow{2}{*}{ Independent Variable } & \multirow{2}{*}{ Dependent Variable } & intervening & \multicolumn{3}{|c|}{ Effect } & \multirow{2}{*}{ v-value } \\
& & variable & Direct & Indirect & Total & \\
\hline Profitability & Dividend policy & & $-0,156$ & & -0.156 & 0,018 \\
\hline Profitability & Firm value & & 0,125 & & 0,115 & 0,046 \\
\hline Profitability & Firm value & $\begin{array}{c}\text { Dividend } \\
\text { Policy }\end{array}$ & & $-0,01$ & & 0.423 \\
\hline CGS & Dividend policy & & 0,226 & & 0,226 & 0,001 \\
\hline CGS & Firm value & & 0,258 & & 0,273 & $<0,001$ \\
\hline CGS & Firm value & $\begin{array}{c}\text { Dividend } \\
\text { Policy }\end{array}$ & & 0,015 & & 0.389 \\
\hline Dividend policy & Firm value & \multicolumn{2}{|c|}{0,067} & & 0,067 & 0,186 \\
\hline
\end{tabular}

1. Profitability is a negative and significant effect on dividend policy with the p-value is a $0.018>0.05$ and the coefficient of -0.156 . This means that the high profitability will progressively Decrease the dividend policy. Based on the results of statistical analysis in this study, it was found that the first hypothesis $\left(\mathrm{H}_{1}\right)$ is accepted and it can be concluded that profitability and significant negative effect on dividend policy. This means that if increasing the profitability of the dividend payment will also increase of. This is in line with the theory that pioneered by Brigham \& Houston (2001) Explains that profitability is a major determinant as consideration of the payment of dividends. The higher profitability indicates better management in running the company's operations. Companies that have high profitability will usually Also high dividends. The results of this study rejected the claim put forward by Mahendra (2011) that companies that Obtain huge profits growing niche to pay greater dividends. The greater the benefits will be greater the company's ability to pay dividends. The results support the theory put forward by Jensen, Solberg and Zorn (1992) cited in Nuringsih (2005) the which states that companies with a high level of profitability will pay dividends in low numbers, otherwise if the company received a lower profitability, the company will Increase the payment of dividends, it is intended to maintain the reputation of the company in order to Werner good from the standpoint of investors.

2. Profitability is a positive and significant effect on firm value with the p-value is a $0.046>0.05$ and the coefficient of 0.125 . This means that the high profitability will be increase the firm value. The second hypothesis $\left(\mathrm{H}_{2}\right)$ is received and it can be concluded that profitability and significant positive effect on firm value. This means that if profitability is increasing the value of the company will also increase. This is According to the theory pioneered by Weston and Brigham (2001), the states that the profitability as measured by ROA high Reflects the position of a great company that provided the market value reflected in the stock price of the company will also be good. This Research relevant to Husnan (2001) that the better growth prospects for the company means the company's profitability in the future rated the better, meaning that the value of the company will also be judged the better in the eyes of investors. If the company's ability 
to generate income increases, the share price will also increase of. Thus Space the higher this ratio, the better the company's position, the means the greater the company's ability to cover the investment being used. This could allow the company to finance the investment of funds from internal sources is available in retained earnings, so the information in the ROA would be a positive value for investors and could increase of the value of the company. This study supports the previous results of other studies by Rahayu (2007); Iqbal (2012); Pakpahan (2010); Susanti (2010); Soliha \& Taswan (2002); Mahendra DJ (2011), that profitability as measured by ROA is a positive and significant effect on firm value. This study rejects the findings Gultom \& Sharif (2009) that the profitability (EPS) had no significant effect on firm value.

3. Profitability have a negative and insignificant effect on the value of the company through dividend policy with the p-value is a $0.423>0.05$ and the coefficient of -0.01 . This means that the better profitability of lowering the dividend policy but has no impact on the value of the company. Results of testing the third hypothesis $\left(\mathrm{H}_{3}\right)$ is not acceptable, that profitability and significant negative effect on firm value. This indicates that an Increase or Decrease in the level of profitability will not significantly affect dividend policy. Coefficient of influence between the profitability of the firm value through dividend policy is $0.01 \%$, it means that the influence of a direct relationship between the profitability of the company's value through dividend policy if the magnitude of the effect will Decrease by $-0.01 \%$. Profitability significant positive effect on firm value, but the impact will be reduced by $-0.01 \%$ when through dividend policy.

4. Corporate governance structures is a positive and significant effect on dividend policy with the p-value is a $0.000>0.05$ and the coefficient of 0.226 . This means that the better the corporate governance structure, the more increase of the dividend policy. Results of testing the fourth hypothesis $\left(\mathrm{H}_{4}\right)$ proved to be acceptable, so that it can be concluded that the structure of corporate governance is positive and significant effect on dividend policy. Reviews these results support the notion by Sunarto \& Kartika (2003: 8), that every factor CG there are still some factors that affect also the company's dividend policy, among others, the debt ratio, total assets, and profitability. The greater the size of the company and its profitability, the greater the dividend will be distributed. Conversely the greater the company's debt level, the lower the dividend to be distributed. Kowaleski et al. (2007) found that the CG is an important factor determinant of dividend policy in Poland. Companies that have a strong CG will pay high dividends, whereas companies that have a weak CG will pay a lower dividend. Also the results show that large enterprises with high profitability and has strong CG, will pay higher dividends than companies with high debt levels and have weakened CG. Furthermore it is said that companies with strong CG practices reflect the rights of the shareholders in the company strong. And vice versa if the CG practices are weak, then the shareholders in the company is weak. The strength of shareholder rights appear in the AGM, shareholders whose rights are strong will have a strong influence in the decision making of the company.

5. Corporate governance structure has a positive and significant effect on firm value with the $\mathrm{p}$-value is a $0.000<0.05$ and the coefficient of 0.258 . This means that the better the corporate governance structure of the company's value increases. Results of testing the fifth hypothesis $\left(\mathrm{H}_{5}\right)$ proved to be acceptable, so it was concluded that the structure of corporate governance and significant positive effect on firm value. Supports the findings by Rustiarini (2010) that some of the things that can lead to corporate governance affects the value of the company, namely: (1) high awareness of the company to implement GCG as a necessity, not simply compliance with existing regulations, (2) management companies interested in long-term benefits GCG implementation, (3) the increased ownership by management and institutional investors led to pressure on the company to apply GCG even greater, (4) the existence of board of directors and audit committee within the company can monitor the companies in implementing good corporate governance, (5) an element of a growing culture The national business environment is supporting the development of GCG implementation. Besides the magnitude of the variation in the implementation of corporate governance mechanism led to corporate governance are factors that have a significant impact on increasing the market value of shares of the company (Black, Jang and Kim, 2003). The higher the GCG Score indicates that the better implementation of corporate governance at the company followed by a higher stock price. Aljifri et al. (2007) cited in Natalia (2012: 11) states that the industrial sectors that there is going to adopt the policy, measurement, and accounting valuation and disclosure of different techniques.

6. Corporate governance structure has a positive and insignificant effect on firm value through dividend policy with the p-value is a $0.389>0.05$ and the coefficient of 0.015 . This means that a good corporate governance structure will improve the dividend policy but has not been an impact on firm value. The sixth hypothesis $\left(\mathrm{H}_{6}\right)$ is not acceptable, so it was concluded that the profitability is a positive and insignificant effect on firm value. These findings support Irrelevant Dividend Theory (Miller and Modigliani, 1961: 411), that there is no effect of dividend policy to be decided or implemented company to company value (assets) owned by the company. Investors who own shares in the company will not be affected on the value of assets / investments when companies do or decide to distribute dividends. This happens because of the effect of the dividend payment policy that does not affect the value of the company, dividend payment policy is 
determined by profitability and shareholders' resolutions. Supports the findings by Blair (1995: 111), that shareholders have an influence on the manager. Although not directly run the company, they have the authority to select and appoint a board of directors. While the board of directors to employ or dismiss a manager. Thus, shareholders have control over managers, one of them in the determination of corporate dividend policy

7. Dividend policy has a positive and insignificant effect on firm value with the p-value is a $0.186>0.05$ and the coefficient of 0.067 . This means that a good dividend policy has not been able to increase the value of the company. The results of the seventh hypothesis $\left(\mathrm{H}_{7}\right)$ are not acceptable. It was concluded that the profitability and no significant positive effect on firm value. The results of different studies the theory of bird-in-the hand which is posed by Myron Gordon \& John Lintner (1959) cited in Brigham (2001: 67), that the company's value will be maximized by the dividend payout ratio is high, as investors assume that the risk of a dividend is not as big as the rise cost of capital, so that investors prefer profits in dividends than expected gains from capital appreciation. Supporting research by Susanti (2010); Perdana (2012), which states that the dividend policy of significant and positive impact on corporate value.

\section{Conclusion}

Profitability is a negative significant effect on dividend policy (direct). Profitability has a positive and significant effect on firm value (direct). Profitability have a negative and insignificant effect on firm value as a mediated of dividend policy (indirect effect). Corporate governance structure has a positive and significant effect on dividend policy (direct). Corporate governance structure has a positive and significant effect on firm value. Corporate governance structure is a positive and significant effect on firm value as a mediated dividend policy (indirect). Corporate governance structure is a positive and significant effect on firm value (direct). The manufacturing sectors listed in Indonesia Stock Exchange is expected to pay attention to managerial opportunistic behavior, thus increasing the dividend policy and corporate value. To the management of manufacturing Sectors listed in Indonesia Stock Exchange is expected to give priority to the corporate governance structure, thus increasing the dividend policy and corporate value. The investors or potential investors for very necessary to conduct an analysis of opportunistic managerial behavior and corporate governance structure before making investment decisions on manufacturing companies listed in Indonesia Stock Exchange. The aim is that the investor can predict the prospect of the behavior and corporate governance in order to guarantee the fundamental aspects of running according to the standards and company policies to get the level of safety and high profits. Companies are expected to keep improving the corporate governance mechanisms well, because the mechanisms of good governance will provide protection of the interests of corporate managers and shareholders to regain operational control over a transparent, reasonable investment, precise and efficient, and to ensure that management acts in accordance with the corporate governance that has been standardized for the benefit of stakeholders.

Recommend to the advanced researchers to re-analyze the managerial opportunistic behavior so as to increase the dividend payout. Analyze the steps of corporate strategy with attention to indicators of profit margin, ROA, ROE in optimizing the profitability and liquidity of the company so as to increase the prosperity of shareholders (principal). Subsequent researchers are advised to analyze the profitability of using an indicator variable profit margin, ROA, ROE and add Independent Commissioner Board as a supervisory agent and Institutional Ownership.

References

[1] Ahmad, J., (2007), "The Effect of Litigation Risk and Strategy mode on Conflicts of Interest and the relationship between accounting conservatism", National Symposium Papers Accounting set X

[2] Al-Matari, YES, Al-Swidi, AK, Fadzil, FHB, Fadzil, H., \& Al-Matari, EM (2012). Board of directors, audit committee characteristics and the performance of Saudi Arabia listed companies. International Review of Management and Marketing, 2 (4), 241.

[3] Amman, M., Oesch, D., \& Schmid, M. (2009). Corporate Governance and Firm Value: International Evidence. St. Gallen: University of St. Gallen.

[4] Anantara, K. Fridagustina. (2013). Effect of Share Ownership Structure and Corporate Social Responsibility in the Value of the Company. Journal of Economic Studies Bulletin, Vol.18. No.2.

[5] Atika Jauhari Hatta, (2002), Factors - Factors Affecting the Policy. Dividend: Investigation. Stakeholder Influence, JAAI Vol. 6, No. 2

[6] Black, BS, Jang, H., \& Kim, W. (2003). Does Affect corporate governance firm value ?: Evidence from Korea. University of Chicago Law School, Law and Economics Workshop.

[7] Brigham, EF and LC Gapenski. (1996). "Intermediate Financial Management". Fifth Edition, New York: The Dryden Press

[8] Brigham, Eugene \& Joel F. Houston, (2001). "Financial Management", Eighth Edition, Book Two, Translation Dodo Suharto, Herman Wibiwo: Editor, Yanti Sumiharti, Wisnu Chandra Kridhaji, Erland, Jakarta.

[9] Brigham, Eugene F. \& Joel F. Houston, (2001). Fundamentals of Financial. Management, Ninth Edition, Horcourt College, United States of America

[10] Carningsih. 2010. Effect Of The Relationship Between Corporate Governance Financial Performance With Corporate Value (Case Study At Company Property and Real Estate Indonesia). Accounting journal. Darsono, A. (2009). Applications Financial Statement Analysis. Yogyakarta: Liberty. Journal of Information Science and Technology, 6 (2), 49-59. 
[11] Desemliyanti. (2003). "Analysis of the factors that determine the value of the company: a review of the agency theory", the undergraduate thesis, University of Atma Jaya

[12] Ellili, NOD, \& Farouk, S. (2011). Examining the capital structure determinants: empirical analysis of companies traded on the Abu Dhabi Stock Exchange. International research journal of finance and economics, 67, 82-96.

[13] Generous, Sjahrial. (2002). Financial Management, 3rd Edition, Partner Discourse, Medan.

[14] Gitman, Lawrence J. (2003), "Principles of Managerial Finance", International. Edition, 10 th edition, Pearson

[15] Gordon, MJ (1962). The investment, financing, and valuation of the corporation. RD Irwin.

[16] Hermuningsih, S., \& Wardani, DK (2009). Factors that affect the value of the company on the companies listed on the stock exchanges of Malaysia and the Indonesian stock exchange. Journal of Business Strategy, 13 (2).

[17] Husnan, Suad. (2001). Fundamentals of Securities Portfolio Theory and Analysis, Third Edition. Yogyakarta: UPP AMP

[18] Iqbal Bukhari, (2012). Empirical Effect of Good Corporate Governance and Corporate Performance Against Company Size (Empirical Study on Companies Listed in Indonesia Stock Exchange). Dipoengoro Kournal of Accounting, volumen 1, Number 2, Year 2012, 1-12.

[19] Iskander, MR, \& Chamlou, N. (2000). Corporate governance: A framework for implementation. World Bank Publications.

[20] Ismiyanti, F., \& Hanafi, MM (2003). Managerial Ownership, Institutional Ownership, Risk, Debt Policy and Dividend Policy: Analysis of Simultaneous Equations. Accounting National Symposium VI, 260-277.

[21] Jensen, M., \& K. Murphy. (1990). "Performance Pay and TopManagement Incentives." Journal of Political Economy 98: 225-64.

[22] Lintner, J. (1962). Dividends, earnings, leverage, stock prices and the supply of capital to corporations. The review of Economics and Statistics, 243-269.

[23] Marlina, L., \& Danica, C. (2009). Analysis of Effect of Position Cash, Debt To Equity Ratio, And Return On Assets Of Divident Payout Ratio.

[24] Maryam, Sitti. (2014). Analysis of Effect of Firm Size, Growth, Leverage, And Profitability Of Company Value (Study at Manufacturing Companies Listed on the Indonesia Stock Exchange). Hasanuddin University, Makassar.

[25] Mehrani, S., Moradi, M., \& Eskandar, H. (2011). Ownership structure and dividend policy: Evidence from Iran. African Journal of Business Management, 5 (17), 7516

[26] Miswanto, H. (1999). The Effect of Operating Leverage, cyclicality and Company Size on Business Risk. Gadjah Mada International Journal of Business, 1 (1), 29-43.

[27] Modigliani, F \& Miller, MH (1958). The Cost of Capital, Corporation Finance and the Theory of Investment. The American Economic Review. 13 (3): 261- 297

[28] Moradi, NS, Aldin, MM, Heyrani, F., \& Iranmahd, M. (2012). The effect of corporate governance, corporate financing decision and ownership structure on firm performance: a data panel approach from Tehran stock exchange. International Journal of Economics and Finance, 4 (6), 86.

[29] Naceur, SB, \& Goaied, M. (2002). The relationship between dividend policy, financial structure, profitability and firm value. Applied Financial Economics, 12 (12), 843-849.

[30] Navissi, F., \& Naiker, V. (2006). Institutional ownership and corporate value. Managerial Finance, 32 (3), 247-256.

[31] Nuringsih, K. (2005). Analysis of the effect of managerial ownership, debt policy, and the size of the company's roa Against dividend policy: a study from 1995 to 1996. Journal of Accounting and Finance Indonesia, 2 (2), 103-123.

[32] Obradovich, J., \& Gill, A. (2013). The impact of corporate governance and financial leverage on the value of American firms.

[33] Pakpahan, Rosma. (2010). Influence Factors Fundamental Dividend Policy Against Company and Corporate Values. Economic Journal

[34] Prasetyorini, Bhekti Fitr. (2013) .Effect of Firm Size, Leverage, Price Earning Ratio and Profitability of the Company Values. Journal of Management Science, 1 (1): 183-196

[35] Priambodo, Midshipman Johni., Topowijono \& Devi Farah Azizah. 2014. Effect of Asset Structure, Growth rate Profitability on sales structure and capital. Journal of Business Administration (JAB), 9 (1), pp: 1-8.

[36] Purwaningtyas, FP, \& Pangestuti, IRD (2011). Analysis of Effect of Good Corporate Governance Mechanism Against Corporate Values (Empirical Study on Manufacturing Companies Listed on the Stock Exchange 2007-2009) (Doctoral dissertation, University of Diponegoro).

[37] Qureshi, MA, \& Azid, T. (2006). Did they do it differently? Capital structure choices of public and private sectors in Pakistan. The Pakistan Development Review, 701-709.

[38] Rachmawati, A., \& Triatmoko, H. (2007). Analysis of factors affecting the quality of earnings and corporate value. Accounting X National Symposium, 1-26.

[39] Rahman, AWS, and Triani, NNA (2013). Effect of free cash flow, dividend policy and the size of the company's capital structure manufacturing companies listed on the Indonesian stock exchange period.

[40] Ratih, S. (2011). Effect of Good Corporate Governance of the Company with a Financial Performance Values as an intervening variable in Winning Companies The Indonesian Most Trusted Company-CGPI. Entrepreneurship Journal, 5 (2), 18-24.

[41] Riyanto, Bambang. (2010). Fundamentals of Company Spending, Edition 4 Yogyakarta: BPPE

[42] Rosdini, D. (2009). The influence of free cash flow to the dividend policy. Abstract.

[43] Rudianto, PA (2009). Concepts and techniques of breastfeeding financial statements. Erland, Jakarta.

[44] Sadalia, Isfenti. (2010). Financial management. Terrain: USU Press

[45] Saputra, M. (2012). Against the Influence of Corporate Governance Corporate Values Stock Exchange Indonesia, Jakarta. Indonesian Journal of Applied Economics, 4 (1).

[46] Sartono, A. (2001). Financial management theory and application. Yogyakarta: BPFE

[47] Siallagan, H., \& Machfoedz, MU (2006). Corporate governance mechanisms, quality of earnings and corporate value. Accounting National Symposium IX. Padang, 23-26.

[48] Sudarsi, Sri. (2002). Analysis of Factors Influencing the Dividend Payout Ratio in the Banking Industry are Listed on the Jakarta Stock

[49] Tarjo. 2008. Effect of Institutional Ownership Concentration and Leverage to Profit Management, Shareholder Value and Cost of Equity Capital. Accounting National Symposium XI, Pontianak.

[50] Wimelda, L \& A. Marlinah. (2013). Variable-Variables Affecting Capital Structure Public Enterprises Non Financial Sector. Journal of Business and Accountancy. Vol. 10 (2): 200-213.

Muhammad Tamrin Effect of profitability and dividend policy on corporate governance and firm value: Evidence from the Indonesian manufacturing Sectors." IOSR Journal of Business and Management (IOSR-JBM), vol. 19, no. 10, 2017, pp. 66-74 